\begin{tabular}{ll}
\hline Jurnal Scripta Teologi dan Pelayanan Kontekstual & \\
ISSN 2086-5368 (Print) & STT Ebenhaezer \\
ISSN & STTE \\
Http://ejournal.stte.ac.id & \\
Vol.3, No.1, pp. 60-74, 2018 &
\end{tabular}

\title{
Makna Ungkapan "Karna Di Mana Hartamu Berada Di Situ Juga Hatimu Berada" Dalam Lukas 12: 34 Dan Implikasinya Bagi Pertumbuhan Iman Jemaat Yanjumseby Y. Manafe
}

STT Ebenhaezer Tanjung Enim, manafeseby2@gmail.com

\begin{tabular}{l} 
INFO ARTIKEL \\
\hline Sejarah Artikel: \\
Diterima : 02 Mei 2018 \\
Direvisi : 10 Mei 2018 \\
Disetujui: 16 Mei 2018 \\
Dipublikasi: 28 Mei \\
2018
\end{tabular}

Kata Kunci:

Makna, Hartamu,

Lukas, Implikasi,

Pertumbuhan, Iman

Keywords:

keyword one, keyword two, keyword three.

\begin{abstract}
ABSTRAK
Harta benda merupakan berkat dari Tuhan, tetapi bagi orang Kristen harta benda bukanlah berkat terbesar, karena yang merupakan berkat terbesar ialah harta rohani. Makna ungkapan "Karena di mana hartamu berada di situ juga hatimu berada" dalam Matius 12: 34, sangat penting untuk dipahami dalam kehidupan dan pertumbuhan iman jemaat. Karena akan berdampak buruk bagi orang percaya dalam kehidupannya jika orang percaya mengutamakan harta dunia ini. Selanjutnya orang Kristen yang mengabaikan harta rohani dan yang melekatkan hatinya pada harta dunia akan mengakibatkan kemerosotan dalam iman, sebab hidupnya lebih memprioritaskan harta dunia dari pada Tuhan Allah yang jelas-jelas sebagai sumber harta tersebut.

Oleh karena itu bukan harta yang menjadikan orang Kristen berdosa, melainkan sikap hati manusia terhadap materi itulah yang menjadikan seseorang diperbudak oleh harta sehingga jatuh dalam dosa dan meninggalkan Tuhan.
\end{abstract}

\section{ABSTRACT}

Property is a blessing from God, but for Christians, the greatest blessing is property, because it is the greatest blessing of spiritual treasure. The meaning is taken "Because where your treasure is there also your heart is" in Matthew 12: 34, it is very important to understand in the life and growth of the faith of the church. Because it will be bad for believers in their lives if believers put the treasure of this world first. Furthermore, Christians who give up spiritual treasures and who are attached to world treasures will release deterioration in the faith, because they prioritize world treasures rather than the Lord God who is clearly the source of these treasures. 
Therefore it is not a treasure that makes Christians sin, preferring a human heart to material things that make a person enslaved by possessions fall into sin and leave God.

\section{PENDAHULUAN}

Manusia adalah ciptaan Tuhan yang hidup dalam sebuah dunia materi.Materi adalah suatu aspek dasar kehidupan yang jelas tidak mungkin dapat diabaikan.Dunia materi sekarang ini mungkin bersifat sementara, tetapi Alkitab tidak menunjukkan bahwa materi itu sesuatu yang rendah nilainnya. ${ }^{1} J a d i$, materi adalah sesuatu yang dibutuhkan dan penting dalam kehidupan manusia.

Di akhir zaman ini salah satu senjata iblis yang digunakan untuk menyerang dan menekan manusia adalah dengan materi atau harta, pangkat, sex, dan harga diri. Harta dapat diibaratkan sama seperti pisau. Pisau dapat bermanfaat tetapi bisa juga menjadi sesuatu yang jahat dan alat yang berbahaya tergantung bagaimana dipergunakan dan tangan siapa yang memanfaatkan. ${ }^{2}$

Demikian pula halnya harta, dengan harta dapat dikerjakan hal-hal yang membangun, namun dengan harta pula dapat dikerjakan hal-hal yang merusak. Harta kekayaan dapat membuat sebuah pelayanan maju tetapi harta juga dapat membuat pelayanan menjadi hancur. Manusia tidak dapat hidup tanpa materi tetapi sebaliknya manusia juga tidak dapat hidup hanya untuk mengejar harta karena itu akan membawa manusia jatuh dalam kejahatan dan kehancuran.

Namun, yang sering menjadi persoalan utama adalah materi atau harta itu dijadikan sebagai tuan atas hidup manusia. Sehingga materi atau harta itu yang memperhamba seseorang termasuk juga orang percaya. Manusia sekarang mudah sekali diperhamba oleh harta kekayaan. Sehingga, di manapun seseorang berada selalu ditakuti dengan rasa kekhawatiran akan keberadaan harta bendanya.

Selain dari pada itu, kehidupan rumah tangga juga sering diperhamba dengan materi, sehingga terjadilah kekerasan rumah tangga, anak kurang mendapat perhatian karena orang tua yang terlalu sibuk mengumpulkan harta dunia. Materi juga sering digunakan pasangan suami istri untuk alasan bercerai, dan karena materi manusia juga bisa saling membunuh. Sekalipun hal-hal materi adalah pemberian dari Allah bagi kehidupan setiap orang, tetapi kekayaan akan sangat berbahaya bila sudah menjadi berhala dalam kehidupan manusia.

Dalam buku Paul David Tripp juga memaparkan prinsip dari Alkitab yang mana Allah juga berkata bahwa ketika seseorang menempatkan berhala di dalam hatinya, "dia juga menempatkan di hadapannya batu sandungan". Prinsip yang dinyatakan di sini adalah prinsip tentang pengaruh berhala di dalam hati yang tidak terhindarkan. Apa yang mengontrol hidup. Berhala dalam hati akan selalu meletakkan batu sandungan di hadapan diri sendiri. ${ }^{3}$ Dengan demikian, jika seseorang selalu menempatkan hatinya pada berhala yaitu hartanya, ia pasti akan meletakkan batu sandungan di hadapan dirinya sendiri yaitu akan terus hidup dalam kemerosotan iman.

Tuhan Yesus berkata, "Barangsiapa setia dalam perkara-perkara kecil, ia setia juga dalam perkara-perkara besar". Dan jikalau kamu tidak setia dalam hal Mamon yang tidak

${ }^{1}$ Jake Barnett, Harta dan Hikmat, (Bandung: Yayasan Kalam Hidup, 1987), 19.

${ }^{2}$ http://www.gpdi-sejahtera.com/articles/bible-studies/35-pandangan-alkitab-tentang-uang.html/26, diakses 26 Agustus 2013.

${ }^{3}$ Paul David Tripp, Masa Penuh Kesempatan, (Surabaya: Momentum, 2007), 24. 
jujur, siapakah yang akan mempercayakan kepadamu harta yang sesungguhnya? (Luk. 16: 10-11). Perkara-perkara kecil adalah harta kekayaan, harta yang sesungguhnya adalah hal-hal yang bersifat kekal.

Selanjutnya, Tuhan Yesus Kristus juga mengajarkan kepada para pengikut-Nya supaya jangan mengumpulkan harta di bumi. Dia mengajarkan kepada para murid-Nya supaya memikirkan hal-hal di atas, dan mengabaikan penimbunan kekayaan atau bendabenda. Lintah darat, pedagang perantara, penukar uang dan penagih utang orang-orang yang meletakkan hatinya pada kekayaan dan menjadikan emas tuhan mereka secara khusus dicelanya. ${ }^{4}$

Searah dengan itu, Gunaryo Sudarmanto juga mengatakan bahwa:

Sebagai sebuah paham filsafat, materialism dicetuskan oleh Thomas Hobbes pada abad ke-16 ketika dunia sedang mengagungkan superioritas manusia sebagai kaidah tunggal penentu apa yang baik dan benar. Dalam otoritas manusia, "materi" dinobatkan sebagai tolok ukur kebenaran materialnya. Hal-hal yang tidak dapat dibuktikan secara materialnya (kebendaan) dianggap sebagai ketidakbenaran. Pikiran semacam ini telah meniadakan realitas Allah dan kepercayaan kepada-Nya. Akibatnya, manusia telah menempatkan materi di singgasana utama dalam hidupnya, sambil menggeser sang pencipta segala materi. Iman tidaklah semata-mata dimengerti sebagai hubungan rohani dengan Allah, melainkan haruslah berpuncak pada kebenaran material. Jadi, segala sesuatu harus diukur dengan materi. Pemikiran seperti ini telah menyusup dalam benak banyak orang, lalu mengkristal menjadi norma-norma hidup dan diakui secara kultural sebagai falsafah hidupnya. Hingga abad ke-21 ini, tantangan materialism semakin menjadi-jadi. Firman Tuhan sudah menegaskan bahwa pada akhir zaman, manusia semakin mencintai dirinya sendiri dan menjadi hamba uang (1Tim. $3: 2){ }^{5}$

Dengan demikian, jemaat Tuhan tetaplah harus hati-hati terhadap ancaman di atas dan memahami dengan benar hakikat materi sebagai ciptaan Tuhan dan kegunaannya bagi manusia dalam kehidupan sehari-hari.

Kasus lain dalam Alkitab yang pertama, menerangkan sangat jelas tentang harta dan benda yang dikaruniakan Tuhan kepada manusia untuk diterima dan digunakan, namun berbahaya jika harta yang menjadi prioritas dalam kehidupan orang percaya. Tolehan istri Lot justru menunjukkan harta yang sudah dikumpulkan dengan bekerja, lebih diutamakan dari pada keselamatan. Oleh karena hati istri Lot terletak pada harta bendanya dari pada keselamatan di dalam Tuhan, maka akhir hidup isteri Lot berujung pada kematian bersama dengan hartanya.

Kedua, Alkitab menjelaskan panggilan Kristus bagi umat-Nya ialah untuk penyerahan diri yang merupakan panggilan untuk menentukan prioritas yang benar dalam hidup. Ini merupakan panggilan bagi hamba Tuhan untuk tidak sibuk bekerja sehingga mengabaikan ibadah, yang merupakan panggilan untuk bersekutu dengan Dia. Yesus mengajarkan hal ini dalam kunjungannya kepada Maria, Marta dan Lazarus di rumah mereka di Betania (Luk. 10: 39). ${ }^{6}$ Jawaban Yesus memperlihatkan kepada Marta, tentang bahaya dari kesibukan yang berlebihan, sebaliknya Yesus menggambarkan apa yang dikerjakan Maria sebagai hal yang perlu, yang baik, dan kekal dengan menyediakan $257-258$.

${ }^{4}$ George Sandison dan staff, Bible Answer For 100 Difficult Questions, (Malang: Gandum Mas, 2006),

${ }^{5}$ Gunaryo Sudarmanto, Menjadi Pelayan Kristus yang Baik, (Malang: Departemen Multimedia (Bidang Literatur) YPPII, 2009), 37

${ }^{6}$ Paul W. Powell, Murid Sejati, (Bandung: Yayasan Kalam Hidup, 1982), 56. 
waktu bagi persekutuan dengan Dia, mendengarkan perkataan-Nya dan menjadi muridNya.

\section{KAJIAN LITERATUR}

\section{Sub Judul 1}

Kajian literatur dapat disajikan menggunakan sub judul sesuai dengan kebutuhan. Bagian ini berisi tentang kajian penelitian terdahulu yang relevan dan dapat memperjelas kebaruan artikel yang hendak dipublikasikan. Memilih literatur yang relevan dengan topik penelitian peneliti, dan menjelaskan bagaimana artikel peneliti memenuhi gap dan menjawab beberapa pertanyaan dalam lapangan penelitian. Kajian literatur secara sederhana bukanlah ringkasan litaratur-literarut (seperii buku, artikel, dan laporan penelitian) yang telah peneliti baca sebelumnya, dan bukan juga deskripsi kronologis dari literatur, tetapi suatu analisis penelitian yang telah dilakukan, dan analisis keberadaan literatur yang berkaitan dengan penelitian peneliti. Kajian literatur sebaiknya $60 \%$ berasal dari jurnal sepuluh tahun terakhir.

\section{METODE PENELITIAN}

Metode adalah cara kerja untuk dapat memahami suatu objek. Karya ilmiah ini, penulis menggunakan metode deskriptif bibliologis. Metode deskriptif adalah metode penelitian dengan cara mengumpulkan data, memberikan gambaran dan penegasan suatu konteks atau gejala serta menjawab pertanyaan yang berhubungan dengan subyek penelitian ini. 7 Metode ini meneliti status sekelompok manusia atau suatu masyarakat, suatu kondisi, sistem pemikiran, atau peristiwa masa kini. Dalam tulisan ini, penulis menggunakan metode deskriptif-bibliologis dalam upaya mewujudkan maksud dan tujuan dari tulisan ini.

Dikatakan sebagai Penelitian Biliologis, adalah karena yang dijadikan landasan atau acuan berpikir penelitian dan teori yang digunakan adalah bersumber dari Alkitab sebagai Firman Allah (Biblika). Sehingga Alkitab dipakai menjadi tolak ukur sebuah prinsip kebenaran dari hal yang dilakukan dan di teliti, kebenaran Yang dimaksud adalah makna ungkapan "jangan hidup lagi sama seperti orang-orang yang tidak mengenal Allah dengan pikirannya yang sia-sia" menurut Lukas 12: 34 .

\section{Hasil Dan Pembahasan \\ Makna Ungkapan "Karena Di Mana Hartamu Berada Di Situ Juga Hatimu Berada" Dalam Lukas 12: 34}

Pada bagian ini, penulis akan menguraikan tentang makna ungkapan menurut Injil Lukas 12: 34. Berturut-turut penulis akan membahas latar belakang Injil Lukas, analisa konteks Injil Lukas 12: 34 baik konteks sebelum maupun konteks sesudah, dan analisa teks Injil Lukas 12: 34, dan makna ungkapan "Karena di mana hartamu berada, di situ juga hatimu berada" dalam Lukas 12: 34.

\section{Latar Belakang Injil Lukas}

Injil Lukas adalah salah satu dari empat tulisan yang mengawali Perjanjian Baru.Injil Lukas digolongkan sebagai Injil Sinoptik bersama dengan Injil Matius dan Markus.Injil Lukas adalah Injil yang terpanjang di antara ketiga Injil. Injil Matius terdiri dari 1.071 ayat, Injil Markus 678 ayat, dan Injil Lukas terdiri dari 1.151 ayat. Isi

\footnotetext{
${ }^{7}$ Sumanto, Metode Penelitian Sosial dan Pendidikan, (Yokyakarta: Andi Offset, 1990), 109
} 
pemberitaannya mengenai kehidupan dan pelayanan Tuhan Yesus,ditulis oleh orangorang tertentu dalam lingkungan jemaat, dan dalam zaman tertentu, serta dengan maksud tertentu. Untuk mengerti atau memahami dari Injil Lukas, maka harus dipahami terlebih dahulu latar belakang penulisannya.

\section{Analisa Konteks}

Kata konteks dipakai untuk menunjukkan hubungan yang menyatukan bagian Alkitab yang hendak ditafsir dengan sebagian atau seluruh Alkitab.Analisa konteks dibagi dalam pengertian konteks dekat dan konteks jauh. Di bawah ini penulis akan menguraikan mengenai konteks dari Lukas 12: 34, baik konteks sebelum maupun konteks sesudah.

\section{Konteks Sebelum Teks Injil Lukas 12: 34}

Konteks sebelum dari teks Injil Lukas 12: 34 ini berbicara tentang Tuhan Yesus yang pada umumnya dipandang sebagai Rabi (Guru), maka tidaklah mengherankan bahwa orang meminta pendapat-Nya tentang suatu perkara, suatu perkara tentang hak milik; barangkali seorang adik dirampas bagiannya atas suatu warisan. Yesus menolak untuk memutuskan perkara itu, sebab la bukanlah Rabi yang ditahbiskan. Tapi la menggali sampai kepada dasar perkara itu dengan memberi peringatan keras terhadap ketamakan (Luk. 12: 13-21). ${ }^{8}$

Ketamakan adalah suatu rasa haus yang tidak dapat terpuaskan untuk memperoleh lebih banyak lagi sesuatu yang kita pikir, kita butuhkan untuk benar-benar dipuaskan. Itu dapat berupa kehausan akan uang atau hal-hal yang dapat dibeli dengan uang, atau bahkan kehausan akan kedudukan dan kekuasaan. Yesus menjelaskan bahwa hidup benar tidak bergantung pada kelimpahan harta milik. la tidak menyangkal bahwa kita memiliki kebutuhan-kebutuhan dasar tertentu (Mat. 6: 32, 1 Tim. 6: 17). ${ }^{9}$

Dengan demikian, Tuhan Yesus hanya menegaskan kembali bahwa kita tidak akan membuat hidup menjadi lebih kaya dengan memperoleh hal-hal duniawi lebih banyak. Pada kenyataannya banyak orang Kristen yang hidup dalam ketamakan dan tidak menyadarinya. mereka berpikir bahwa peringatan Paulus dalam 1 Timotius 6 hanya berlaku bagi "orang-orang kaya dan terkenal".

Selanjutnya, Tuhan Yesus menjelaskan bahwa hidup benar tidak berasal dari kelimpahan harta, begitu juga keberhasilan dan rasa aman yang sesungguhnya. Apakah artinya menjadi "kaya di hadapan Allah"? Itu berarti mengakui dengan penuh rasa syukur bahwa berasal dari Allah, dan kemudian melakukan suatu usaha untuk menggunakan apa yang diberikan-Nya kepada setiap orang bagi kebaikan orang lain dan bagi kemuliaan Allah. ${ }^{10}$

Jadi, menjadi kaya di hadapan Allah berarti memiliki pengayaan rohani, dan bukan hanya kenikmatan pribadi. Betapa tragisnya ketika orang menjadi kaya di dunia ini, tetapi miskin di kehidupan yang akan datang.

${ }^{8}$ L.H. Marshall dan P.S. Naipospos, Tafsiran Alkitab Masa Kini 3 Matius-Wahyu (Jakarta: Yayasan Komunikasi Bina Kasih, 2008), 224.

${ }^{9}$ Warren W. Wiersbe, Berbelaskasihan di Dalam Kristus (Bandung: Yayasan Kalam hidup, 2002), 150.

\footnotetext{
${ }^{10}$ Ibid...,154-155.
} 


\section{Konteks Sesudah Teks Injil Lukas 12: 34}

Konteks sesudah Injil Lukas 12: 34 ini berbicara tentang Yesus yang mengalihkan penekanan-Nya dari kekhwatiran tentang masa kini kepada hal berjaga-jaga terhadap masa depan. Oleh karena itu, manusia harus mengarahkan pikiran sepenuhnya kepada Kerajaan Allah bukan kepada hal-hal duniawi, selanjutnya Yesus mengalihkan pembicaraan-Nya kepada mereka, bahwa bukan hanya pikiran saja tetapi harus disertai oleh sikap yang harus berpusat pada kehidupan yang akan datang. ${ }^{11}$

Artinya, dalam pengertian yang lebih sempit mengacu kepada kedatangan Yesus yang kedua, sedangkan dalam pengertiannya yang lebih luas ia menunjukkan kepada saat ketika panggilan Allah memasuki kehidupan manusia, suatu panggilan untuk bersiap-siap bertemu dengan Allah. ${ }^{12}$ Dengan jelas Tuhan menyuruh mereka untuk menyimpan harta mereka di sorga, supaya mereka dapat masuk menikmati harta mereka, yaitu hidup yang kekal di Kerajaan Sorga.

Selanjutnya, dapat dipahami bahwa tema-tema dalam Lukas 12 berjalan seiring karena salah satu cara terbaik untuk mengatasi kemunafikan, ketamakan, dan kekhawatiran adalah dengan menantikan kedatangan Tuhan. ${ }^{13}$ Dengan demikian, ketika manusia "hidup untuk masa yang akan datang" , sulit bagi hal-hal duniawi untuk memikat manusia. Dalam bagian ini sangat jelas bahwa Yesus menjelaskan bagaimana kita dapat bersiap untuk menyambut kedatangan-Nya.

\section{Analisa Teks Injil Lukas 12: 34}

Pada bagian ini penulis akan memaparkan analisa teks injil Lukas 12: 34 yang meliputi, latar belakang teks injil Lukas 12: 34, dan struktur teks dan terjemahannya.

\section{Latar Belakang Teks Injil Lukas 12: 34}

Latar belakang dari Injil Lukas 12: 34 berbicara tentang perdebatan-perdebatan orang-orang Palestina yang membingungkan kepada Rabi-Rabi yang dihormati, tetapi Yesus menolak untuk dikaitkan dengan perdebatan-perdebatan orang mengenai uang. ${ }^{14}$ Oleh karena murid-murid Kristus yang terlalu berlebihan mengejar hal-hal duniawi, sekalipun itu diperlukan, maka hal ini sangat tidak baik bagi mereka (12:29-30). ${ }^{15}$

Dengan demikian, Yesus melihat bahwa ini merupakan suatu kesempatan untuk menjelaskan apa sikap pengikut-Nya terhadap hal-hal material. la mesti mengatakan sesuatu itu baik kepada mereka yang mempunyai barang-barang dengan limpahnya dan mereka yang kekurangan.

Terhadap mereka yang mempunyai barang-barang secara berkelimpahan Yesus menceritakan perumpamaan mengenai orang kaya yang bodoh.Yesus juga menunjukan perkataannya kepada mereka yang hanya memiliki sedikit barang. Dalam seluruh bagian ini ajaran yang Yesus tekankan adalah menyangkut kekhawatiran, sebab Yesus melarang orang untuk kuatir. ${ }^{16}$ Kekhawatiran adalah hal yang bercela, kekhawatiran menghalangi pertumbuhan iman dan menjadikan sama dengan orang yang tidak diselamatkan dalam

\footnotetext{
${ }^{11}$ Naipospos, Tafsiran Alkitab..., 225.

12 William Barclay, Pemahaman AlkitabAlkitab Setiap Hari, (Jakarta: BPK Gunung Mulia, 1997),

${ }^{13}$ Wiersbe, Berbelaskasihan di..., 156.

${ }^{14}$ Barclay, Pemahaman Alkitab..., 237.

${ }^{15}$ Matthew Herny, Tafsiran Matthew Henry Injil Lukas 1-12, (Surabaya: Momentum, 2009), 457.

${ }^{16}$ Barclay, Pemahaman Alkitab...., 237-238.
} 240. 
dunia (ayat 30). ${ }^{17}$ Artinya kekhawatiran bukan hal yang Kristiani, jadi kekhawatiran adalah dosa.

\section{Uraian Eksegese Lukas 12: 34 \\ "Karena Dimana Hartamu Berada"}

Pada bagian pasal 12: 34 teks ini di mulai dengan kata ga,r yang merupakan conjunction coordinating merupakan conjunction (kata penghubung) yang memiliki dua pengertian dasar, yaitu pertama, sebagai copulative (kata sambung) yang menggabungkan kata-kata atau kalimat-kalimat, diterjemahkan sebagai "dan". Kedua, sebagai penanda atau penegasan yang ditambahkan pada sesuatu hal yang telah disampaikan, diterjemahkan sebagai "juga, bahkan". ${ }^{18}$ Jadi, dalam konteks ini kata ga,rbisa diterjemahkan sebagai kata penghubung "juga".

Kalimat Dimana Hartamu Berada yang terdapat dalam Lukas 12: 34. Istilah "dimana hartamu berada" dalam bahasa Yunani o[pou ga,r evstin o' qhsauro.j u’mw/n artinya "dimana karena berada hartamu". ${ }^{19}$ New Internasional Version, New American Standart Bible dan King James Version sama-sama menulis "for where your treasure is" artinya "sebab dimana hartamu berada". Istilah evstin (present, orang ke-3 tunggal)

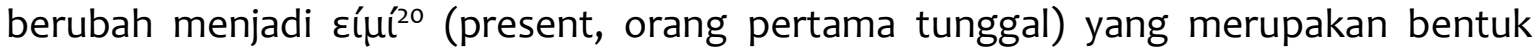
waktu, yang menyatakan sebuah kesungguhan. ${ }^{21}$

Istilah evstin ditulis dalam bentukverb indicative present activeadalah perbuatan yang dilakukan pada masa sekarang dan bersifat terus menerus. Kata ini mempunyai arti berada, adalah, terdapat, tinggal, terjadi, mungkin, sama seperti, artinya atau yaitu. ${ }^{22}$ Berdasarkan kata kerja é́ $\mu$ í yang berarti menyatakan sebuah kesungguhan maka, itu menunjukkan tempat tinggal harta, keberadaan harta benar-benar ada dan bisa dibuktikan secara terus menerus. Oleh karena harta itu benar-benar ada, maka hati seseorang akan berada (e;stai, futurum, orang ketiga tunggal) akan tinggal, dan akan terpaut dan terikat di sana juga.

\section{Pengertian Harta}

Istilah "harta" sendiri ditulis dalam bahasa Yunani qhsauro.j (thesauros). Kata ini ditulis sebanyak 17 kali dan dalam bentuk noun nominative masculine singular common yang berarti kata benda maskulin tunggal yang menyatakan subyek.Kata "harta" berasal dari kata qhsauro.j dengan kata dasar qhsauro.j artinya tempat menyimpan, kotak harta, gudang dan harta. ${ }^{23}$ Isilah harta dalam New American Standart Bible menuliskan: "for where your treasure is", artinya "sebab di mana hartamu berada". ${ }^{24}$ Kata "treasure" di sini berarti harta benda, harta terpendam, harta karun, yang

${ }^{17}$ Wiersbe, Berbelaskasihan di..., 155.

18 __ Bible Work-c\Program Files\bibleworks \init \bw 700.swc

19 Susanto, Perjanjian Baru...,389.

${ }^{20}$ Kata Kerja é́uíberarti "adalah" (bahasa Inggris: to be), dan mempunyai tiga bentuk waktu, yaitu Present, Imperfek dan Futurum.

${ }^{21}$ Ola Tulluan, Diktat, Bahasa Yunani, (Tanjung Enim: STTE Ebenhaezer, 1992), 37.

${ }^{22}$ Susanto, Perjanjian Baru..., 398.

${ }^{23}$ Susanto, Perjanjian Jilid II..., 374.

${ }^{24}$ J. B. McCabe Company, New American Standart Bible, (New York: Thomas Nelson Publiser), 113. 
berharga. ${ }^{25}$ Sedangkan $u^{` m w / n d i t u l i s ~ d a l a m ~ b e n t u k p r o n o u n ~ p e r s o n a l ~ g e n i t i v e ~ p l u r a l ~}$ fromsu,artinya kata ganti orang kedua jamak yang menunjuk kepada kepemilikan. ${ }^{26}$

Dengan demikian, secara jelas istilah o[pou ga,r evstin o` qhsauro.j u`mw/n dapat diartikan bahwa keberadaan harta itu benar-benar ada dan dapat dibuktikan atau dapat dilihat secara nyata yang merupakan hak milik seseorang.

\section{Jenis Harta}

Menurut jenisnya A S Hornby lebih jelas lagi mengartikan "treasure" yaitu berupa dalam bentuk emas dan perak, serta batu permata. ${ }^{27}$ Sedangkan dalam Word Study Series kata qhsauro.j menuliskan "anything laid up in storey" artinya "sesuatu yang diletakkan di suatu tempat". ${ }^{28}$ harta juga dapat dibedakan menjadi dua yaitu harta bergerak dan harta yang tidak bergerak. Harta benda yang bergerak antara lain: kendaraan baik roda dua maupun roda empat, tabungan atau deposito, saham, maupun orang-orang yang terdekat dengan misalnya keluarga (suami, istri dan anak-anak). Sedangkan harta benda yang tidak bergerak biasanya mengacu kepada uang, perak dan emas(Ams. 10: 2; Pkh. 2: 8; Mik. 6: 10).Harta juga dapat berupa permata dan sesuatu yang dianggap sangat berharga atau bernilai, sehingga diletakkan atau disimpan disuatu tempat yang dianggap sangat aman.Karena harta itu sangat berharga maka banyak orang berusaha untuk mengumpulkannya dan memilikinya.

\section{Sumber Harta}

Semua harta atau materi adalah ciptaan Tuhan (Kej. 1: 1-25). Semua "materi" dipercayakan oleh Tuhan untuk "dikuasai" manusia (Kej. 1: 26). Tuhan sendiri mengamanatkan agar manusia memenuhi bumi dan menakhlukkan bumi (Kej. 1: 28). Amanat ini disebut sebagai amanat kebudayaan. Dengan demikian, harta itu sendiri hanya berguna bagi manusia selama ia masih hidup di dunia ini. Amsal 27: 24 mengatakan bahwa, harta tidaklah abadi dan Amsal 11: 4 juga mengatakan bahwa, pada hari kemurkaan harta tidak berguna. ${ }^{29}$

Allah juga menciptakan manusia, harta atau materi, dan telah menetapkan hubungan yang tepat antara keduanya. Alam semesta telah benar-benar berfungsi sebagaimana yang telah dikehendaki oleh Allah sebagai Sang pencipta. Jadi setiap manusia harus memahami apa kehendak Allah atas manusia dan alam materi untuk berfungsi bersama.

Namun, yang sering menjadi masalah di tengah-tengah kehidupan orang percaya mereka lupa akan kehendak Tuhan, terbukti di mana mereka lebih mengutamakan mengejar harta di bumi ini dari pada mengejar sumber harta. Jika hal ini sering terjadi dalam kehidupan orang Kristen pada saat ini, maka orang tersebut tidak akan mengalami pertumbuhan dalam iman. Tetapi iman tersebut hanya di tempat dan bisa jadi akan terus mengalami kemerosotan dalam segi iman dan lama-lama iman tersebut akan mati.

${ }^{25}$ Jhon M. Echols dan Hassan Shadily, Kamus Inggris Indonesia, (Jakarta: PT Gramedia Pustaka Utama, 1996), 602.

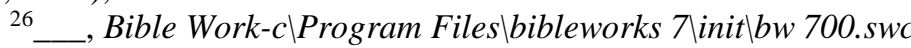

27 A.S Hornby, Oxford Advanced Learner's Dictionary of Current English, (Walton Street: Oxford University Press, 1974), 921.

${ }^{28}$ Spiros Zodhiates, The Complete Word Study Dictionary New Testament, (Chattanoogo: AMG Internasional, 1993), 736.

${ }^{29}$ Sudarmanto, Menjadi Pelayan...,38. 


\section{Tujuan Tuhan Memberikan Harta}

Pada hakikatnya setiap orang Kristen seharusnya hidup untuk memuliakan Allah. Paulus berkata dalam Galatia 1: 10 "sekiranya aku masih mau mencoba berkenan kepada manusia, maka aku bukanlah hamba Kristus. Kemudian dalam suratnya kepada jemaat di Tesalonika, ia menulis "kami berbicara... untuk menyukakan Allah yang menguji hati kita" (1Tes. 2: 4).

Oleh karena itu, menjadi orang Kristen yang biasa-biasa saja tidaklah cukup, tetapi Paulus mengatakan "janganlah kamu menjadi serupa dengan dunia ini, tetapi berubahlah oleh pembaharuan budimu..." (Rm. 12: 2). Saat ini banyak orang yang mengakui dirinya Kristen, tetapi kelakuan, cara berpikir, dan tutur kata mereka sama seperti orang-orang dunia yang tidak mengenal Allah. ${ }^{30}$ Sebab, perilaku baik yang dilakukan setiap umat Tuhan bukanlah untuk mengembangkan diri sendiri atau membanggakan kekristenan saja, tetapi prilaku yang mereka tunjukkan supaya nama Tuhan dimuliakan, dan lewat prilaku mereka Injil diberitakan kepada banyak orang.

Selain dari pada itu, setiap orang percaya harus dapat memahami pandangan Kristen tentang harta yang sangat berlainan sekali dengan pandangan dunia. Pandangan dunia mengatakan bahwa harta merupakansesuatu yang kita peroleh karena usaha kita sendiri, karena nasib baik, atau karena kemujuran. Harta adalah untuk manusia pakai dan demi kepuasannya, dan sangat sering menjadi tujuan akhir. Banyak orang menikmati tantangan dalam mencari harta dan dengan gairah yang sama saat mereka juga menghabiskannya. Dunia melihat harta sebagai hasil dari usaha sendiri, artinya miliknya sendiri.

Pandangan orang Kristen tentang harta yaitu bahwa harta yang manusia miliki tujuannya supaya dapat menggunakannya dengan cara-cara yang mendatangkan kemuliaan bagi Allah. Harta bukan sesuatu yang atasnya manusia mempunyai kekuasaan penuh, manusia hanyalah penatalayan kekayaan Allah.Ilustrasi yang baik tentang prinsip ini terdapat dalam perumpamaan tentang talenta, yang menunjukkan bahwa harta yang diperoleh karena kerja sekalipun bukan merupakan milik kita sebab Allahlah yang sebenarnya memberikan kita kesempatan untuk memperolehnya.

Dalam Efesus 4: 28 Paulus menulis: "Orang yang mencuri, janganlah ia mencuri lagi, tetapi baiklah ia bekerja keras dan melakukan pekerjaan yang baik dengan tangannya sendiri, supaya ia dapat membagikan sesuatu kepada orang yang berkekurangan". Kenikmatan dari pemberian yang indah dari Tuhan harus diimbangi dengan memenuhi kebutuhan mereka yang kekurangan, terutama mereka yang seiman.

Jadi pandangan orang percaya tentang harta adalah bahwa harta itu kita miliki agar kita bisa menggunakannya dengan cara-cara yang mendatangkan kemuliaan bagi Allah.Harta bukan sesuatu yang atasnya manusia mempunyai kekuasaan penuh, orang percaya hanyalah penatalayanan kekayaan Allah. Hal ini menunjukkan bahwa harta yang manusia peroleh karena kerja sekalipun merupakan milik pribadinya sebab Allah memberi kesempatan untuk memperolehnya dan bertujuan untuk kemuliaanNya.Sebab segala sesuatu berasal dari Dia, oleh Dia, dan semestinya harus diarahkan untuk kemuliaan-Nya (Rm 6: 23).

\footnotetext{
${ }^{30}$ Sadikin Gunawan, Menjadi Orang Kristen yang Berbeda, (Jakarta: Yayasan Pekabaran Injil, KAWANAN KECIL, 2003), 15.
} 


\section{Disitu Juga Hatimu Berada}

Tuhan Yesus mengakhiri kalimat-Nya dalam ayat 34 dengan kalimat "di situ juga hatimu berada". Istilah "di situ juga hatimu berada" dalam bahasa Yunani evkei/ kai. h` kardi,a u`mw/n e;stai yang berarti "di situ juga hatimu akan berada". ${ }^{31}$ New American Standart Bible menerjemahkan "there will your heart be also" artinya "di situ akan ada juga hatimu". ${ }^{22}$ Sedangkan New Internasional Version dan King James Version samasama menulis "there your heart will be also" artinya "di situ juga ada hatimu".

\section{Pengertian Hati}

Istilah "hati" dalam bahasa Yunani yaitu kardi,a (kardia). Kata ini ditulis sebanyak 156 kali dan ditulis dalam bentuk noun nominative feminine singular common yang berarti kata benda feminim tunggal yang menyatakan subyek. Kata kardi,aberarti hati dan pusat. Hati dapat menunjuk pada pusat kehidupan fisik manusia, ia juga dapat menunjuk tempat dan sumber kehidupan dalam diri manusia untuk berpikir, merasa, mengambil keputusan umum, atau moral, dan lain-lain. Hati juga dapat menunjuk tempat tinggal Roh Kudus atau Tuhan, ${ }^{33}$ dalam Strong juga menggunakan kata yang sama yaitu "heart".34

\section{Fungsi Hati}

Selanjutnya dalam Exegetical Dictionary juga menggunakan kata kardi,a(kardia) yang memberi pendapat bahwa, The theological meaning of kardi,a is more significan than simple anthropological usage: The kardi,a is the "place" of the person in which the encounter with God is realized in the positive or negative sense, in which religious life has its firm ground, and from which the ethical conduct of the person is determined. ${ }^{35}$ Artinya: fungsi hati adalah sebagai tempat di mana manusia berhubungan pribadi dengan Allah secara nyata, baik dalam perasaan positif maupun negatif dalam kehidupan kerohaniannya, yang dilakukan dalam ketekunan.

A.S Hornby menerjemahkan istilah "hati" merupakan bagian tubuh yang memompa darah, pusat emosi, bagian yang terdalam dalam tubuh manusia, pusat segala-galanya. Kemudian istilah "hati" digambarkan juga sebagai panggilan kasih atau sayang kepada seseorang. ${ }^{36}$ Anton Moeliona menjelaskan lebih detail tentang hati yaitu organ tubuh yang berwarna kemerah-merahan di bagian kanan atas rongga perut yang bertujuan untuk mengambil sari-sari makanan di dalam darah dan menghasilkan empedu, sesuatu yang ada dalam tubuh manusia, yang dianggap tempat segala perasaan batin (kesedihan) dan tempat menyimpan pengertian-pengertian (perasaan). ${ }^{37}$

Berdasarkan uraian di atas, maka dapat dipahami bahwa yang fungsi "hati" adalah sebagai pusat segala-galanya, sebagai jantung kehidupan, sebagai sumber seluruh kehidupan, sebagai tempat untuk mencurahkan perasaan dan emosi, sebagai sumber

\footnotetext{
${ }^{31}$ Susanto, Perjanjian Baru..., 389.

${ }^{32}$ Company, New American ..., 113.

${ }^{33}$ Susanto, Perjanjian Jilid II..., 427.

${ }^{34}$ James Strong, Stong Exhaustive Concordance of The Bible, (Virginia: Hendricson Publishing,
} 1890), 77

35 Horst Balz and Gerhard Schneider, Exegetical Dictionary of The New Testament, (Michigan: Publishing Company, 1991), 250.

${ }^{36}$ Hornby, Oxford Advanced..., 397.

${ }^{37}$ Moeliono, Kamus Besar..., 301. 
pikiran, batin, perasaan sayang dan keamanan, sebagai penerang kehidupan, bahkan juga tempat untuk menyatakan keputusan, keinginan dan harapan. Selain itu hati juga di gunakan untuk menyatakan perasaan positif ataupun negatif, jadi jika seseorang menyatakan perasaan positif tentang harta maka hatinyaakanmelimpah dengan ucapan syukur, dan berserah kepada Tuhan. Tetapi jika perasaan negatif yang ada tentunya hatinya penuh rasa khawatir akan hartanya, baik keberadaannya maupun upaya mendapatkannya.

Hal di atas diperkuat dengan istilah kardi,ayang didampingi dengan kata e;stai... e;stai (berada) ditulis dalam bentuk verb indicative future middle menunjukkan suatu peristiwa namun peristiwa itu akan terjadi di pertengahan/masa depan. ${ }^{38}$ Jadi, "disitu juga hatimu berada" menunjukkan sikap hati yang akan terjadi kedepan.

Menurut Matthew Henry kalimat "di situ juga hatimu berada" memiliki pengertian: Pertama, nilai dan harga diri berada, di situ pula cinta dan perasaan berada. Kedua, perhatian dan kekhawatiran, karena takut kehilangan harta itu, di situ harapan, pikiran-pikiran yang bebas, pikiran yang tetap dan pikiran yang timbul untuk memikirkan apa yang menjadi milik kita. ${ }^{39}$ Artinya, jika seseorang menghargai perkara duniawi, maka hati orang tersebut akan diperbudak olehnya. Dan selanjutnya,jika Kerajaan Allah, perkara sorgawi, Firman-Nya, kehadiran-Nya, kekudusan-Nya, dan hubungan denganNya merupakan harta orang tersebut, maka orang tersebut akan memiliki hubungan pribadi dengan Allah secara nyata, sehingga hatinya akan tertarik kepada perkara Kerajaan-Nya dan hidupnya akan diarahkan ke sorga, sambil menantikan kedatangan Tuhan kembali.

Dengan demikian, kalimat "di situ juga hatimu berada", ini menjelaskan bahwa jika manusia menggangap kekayaan di dunia sebagai harta yang paling penting, maka harta itu akan berada dan tinggal di dalam hati dan menjadi pusat kehidupan, kemudian hati itu akan selalu terpikat oleh harta tersebut. Sehingga fungsi hati yang seharusnya tempat seseorang memiliki hubungan pribadi dengan Tuhan, di jadikan tempat pribadi manusia dengan harta miliknya, inilah yang disebut dengan matrealisme.

Tetapi kalau manusia menganggap harta di sorga yaitu hidup kekalitu lebih berharga dari harta di bumi ini, maka orang tersebut akan meletakkan hati dan pikirannya kepada apa yang dianggapnya lebih berharga. Oleh sebab itu, tampaklah bahwa seseorang menimbun harta di sorga jika hatinya berada di sana sementara ia berada di sini.

\section{Makna Theologis Injil Lukas 12: 34 Hidup Dalam Ketamakan}

Orang-orang Kristen terperangkap dalam suatu kehidupan yang tidak puas karena ikut mengejar sasaran-sasaran duniawi. Sasaran-sasaran itu selalu berkembang menjadi: ingin lebih, semakin lebih lagi, dan mencapai yang paling top. Kitab suci menyebutnya sebagai suatu kegemaran atau ketamakan dan kesombongan..$^{40}$

Lukas 12: 34 sangat jelas mengajarkan kepada orang percaya supaya jangan hidup dalam ketamakan. Dalam Lukas 12: 15 juga mengatakan bahwa "Berjaga-jagalah dan waspadalah terhadap segala ketamakan ...." artinya, awasilah dirimu, jagailah hatimu baik-baik, jangan sampai sikap tamak merasuki hatimu itu, dan memelihara diri dan

\footnotetext{
${ }^{38}$ Susanto, Perjanjian Baru..., 398.

${ }^{39}$ Herny, Tafsiran Injil..., 260.

${ }^{40}$ Larry Burkett, Mengatur Keuangan Dengan Bijak, (Bandung: Yayasan Kalam Hidup, 1985), 19.
} 
bulatkanlah hatimu dengan rapat-rapat, agar jangan sampai ketamakan menguasai dan memerintah di dalam hati, sebab ketamakan adalah dosa yang harus terus diwaspadai, karena siapa saja bisa jatuh dalam dosa ketamakan.

Firman Tuhan di atas jelas mengingatkan kembali kepada setiap orang percaya. Ada banyak orang Kristen yang pandai membenarkan diri sendiri dan bahkan berani menggunakan Firman Tuhan untuk menutupi ketamakannya. Harta dan materi sebenarnya boleh saja dicari dan dimiliki, untuk kebutuhan sehari-hari atau untuk sarana pelayanan kepada Tuhan dan kepada sesama manusia, tetapi yang pasti hidup ini bukan semata-mata hanya untuk mengejar harta duniawi sehingga dapat mengabaikan harta yang bersifat kekal. Oleh sebab itu, hendaklah setiap orang percaya dapat menjauhkan diri dari ketamakan, karena orang yang berhasil mengumpulkan harta dunia sebanyakbanyaknya, akan terbius oleh keindahan hartanya, dan ia sesungguhnya menjadi orang kaya yang miskin di hadapan Allah.

\section{Masuk Dalam Jebakan Materialisme}

Materialisme adalah penyimpangan penyediaan Allah akan dunia materi. Ini merupakan penggeseran kekuasaan, yang menyebabkan manusia tidak menguasai halhal materi, tetapi justru diperbudak olehnya. Bila seseorang hidup untuk mengumpulkan hal-hal materi, ia akan menjadi budak materi tersebut. Perjanjian Baru mengatakan, "Apakah kamu tidak tahu, bahwa apabila kamu menyerahkan dirimu kepada seseorang sebagai hamba untuk mentaatinya, kamu adalah hamba orang itu, yang harus kamu taati ....?" (Rm. 6: 16); dan "Mereka ... menyembah makhluk dengan melupakan Penciptanya" (Rm. 1: 25). ${ }^{41}$

Ayat-ayat di atas menyimpulkan bahwa materialisme adalah perhambaan oleh halhal materi. Jika manusia telah terjebak dalam kehidupan materialisme, maka pola hidupnnya meliputi: cinta uang, suatu keinginan yang tidak terkendalikan akan hal-hal materi, dan dikuasai olehnya. Sehingga manusia lebih percaya bahwa materi dapat memberi keamanan, jadi manusia bersandar kepadanya dan bukannya bersandar kepada Allah. Apabila posisi Tuhan Allah dalam hati orang percaya telah digantikan dengan harta atau materi dunia, maka sama artinya orang tersebut telah menduakan Tuhan dengan harta dunia, yang berakibat jatuh dalam penyembahan berhala. Oleh sebab itu, dengan tegas Lukas mengajarkan supaya orang percaya harus dapat menjauhkan diri dari jebakan-jebakan materialisme, sehingga otoritas Allah dalam hati kita tidak akan tergantikan oleh apapun juga.

\section{Hidup Dalam Kekhawatiran}

Apabila hati manusia sudah terpikat oleh harta dunia dan menempatkan harta itu yang utama, maka mengakibatkan manusia akan selalu dikuasai oleh rasa kekhawatiran yang berlebihan akan harta bendanya. Segala kekhawatiran tidak akan menghasilkan apa-apa, sia-sia dan tidak berguna. Karena itu bodohlah jika manusia terus memikirkannya. ${ }^{42}$

Jadi, jika tidak mampu melakukan hal yang paling kecil, yaitu hal dalam hidup yang tidak dapat di ubah dengan kekuatan sendiri, janganlah terlalu memusingkan diri dengan hal-hal yang lain yang jauh berada di luar kekuatan manusia, yang sesungguhnya bergantung kepada pemeliharaan Allah sepenuhnya. Dengan demikian, hendaklah

\footnotetext{
${ }^{41}$ Jake Barnett, Harta dan Hikmat, (Bandung: Yayasan Kalam Hidup, 1987), 116.

${ }^{42}$ Herny, Tafsiran Injil..., 457.
} 
setiap orang percaya harus bersikap bijaksana dengan menerima setiap keadaan yang ada dan memanfaatkan dengan sebaik-baiknya dengan penuh ucapan syukur, karena kekhawatiran dan penyesalan, keluhan dan kecemasan tidak akan pernah dapat memperbaikinya.

\section{Simpulan}

Jadi Allah sungguh sangat peduli terhadap di mana harta berada, karena di situ jugalah hati akan berada. Jika hati ada pada Tuhan dan segala sesuatu yang berhubungan dengan Tuhan, maka tidak diragukan lagi maka akan bisa memberi kepada Tuhan lebih banyak daripada yang lain. Apa yang dicintai, maka waktunya akan lebih banyak ke sana dan juga akan berinvestasi ke sana. Tuhan tahu hal ini dan Dia juga memperhatikan kemana seseorang menginvestasikan hartanya.

Sebagai contoh, di mana manusia menaruh harta bendanya, di situ pulalah hati mereka berada. Jika seseorang memiliki uang di pasar saham, maka akan sangat tertarik dengan apa yang terjadi di sana. Hati seseorang akan berada di pasar saham. Tetapi jika tidak punya uang di sana, tentu tidak akan peduli dengan apa yang sedang terjadi di sana.

Tuhan tidak benci kepada harta benda, tetapi Dia tidak suka jika manusia mencintai harta bendanya sehingga menempatkan Tuhan dan keluarganya sendiri menjadi tidak lebih penting, ataupun bahkan sampai mau untuk mengorbankan prinsip-prinsip alkitabiah untuk mendapatkannya.

Kedekatan dan keintiman manusia dengan Tuhan dapat dipertimbangkan sebagai kekayaan yang sesungguhnya, sehingga hal yang lebih daripada harta yang bersifat sementara, seperti Cinta kasih, Sukacita, Damai sejahtera akan manusia dapatkan, dan sebenarnya hal itulah yang menjadi kekayaan yang sesungguhnya. Hal-hal ini lebih berharga daripada harta yang berjumlah berapapun, dan materi tidak dapat membeli Kerajaan sorga. Tetapi Tuhan memang memakai harta yang bersifat sementara untuk melihat apakah manusia dapat dipercaya untuk menerima harta sesungguhnya. 


\section{Daftar Pustaka}

Balz, Horst and Gerhard Schneider,

1991 Exegetical Dictionary of The New Testament, Michigan: Publishing Company,

Barclay, William

1997 Pemahaman AlkitabAlkitab Setiap Hari, Jakarta: BPK Gunung Mulia,

Barnett, Jake

1987 Harta dan Hikmat, Bandung: Yayasan Kalam Hidup,

Burkett, Larry

1985 Mengatur Keuangan Dengan Bijak, Bandung: Yayasan Kalam Hidup,

Company, J. B. McCabe

Tt New American Standart Bible, New York: Thomas Nelson Publiser

Gunawan, Sadikin

2003 Menjadi Orang Kristen yang Berbeda, Jakarta: Yayasan Pekabaran Injil, Kawanan Kecil,

Herny, Matthew

2009 Tafsiran Matthew Henry Injil Lukas 1-12, Surabaya: Momentum,

Hornby, A.S

1974 Oxford Advanced Learner's Dictionary of Current English, Walton Street: Oxford University Press

Jhon Echols, M. dan Hassan Shadily, 1996 Kamus Inggris Indonesia, Jakarta: PT Gramedia Pustaka Utama,

Marshall, L.H. dan P.S. Naipospos, 2008 Tafsiran Alkitab Masa Kini 3 Matius-Wahyu Jakarta: Yayasan Komunikasi Bina Kasih,

Morris, Leon

2006 Theologi Perjanjian Baru, Malang: Gandum Mas,

Powell, Paul W.

1982 Murid Sejati, Bandung: Yayasan Kalam Hidup,

Sandison, George

2006 Bible Answer For 100 Difficult Questions, Malang: Gandum Mas, 
Strong, James Strong

1890 Exhaustive Concordance of The Bible, Virginia: Hendricson Publishing,

Sudarmanto, Gunaryo

2009 Menjadi Pelayan Kristus yang Baik, (Malang: Departemen Multimedia Bidang Literatur YPPII

Tripp, Paul David

2007 Masa Penuh Kesempatan, Surabaya: Momentum,

Tulluan, Ola

1992 Diktat, Bahasa Yunani, Tanjung Enim: STTE Ebenhaezer,

Wiersbe, Warren W.

2002 Berbelas kasihan di Dalam Kristus Bandung: Yayasan Kalam hidup,

Zodhiates, Spiros

1993 The Complete Word Study Dictionary New Testament, Chattanoogo: AMG Internasional 